\title{
Dedifferentiated liposarcoma with leukocytosis. A case report of G-CSF-producing soft-tissue tumors, possible association with undifferentiated liposarcoma lineage
}

\author{
Akio Sakamoto*1, Hiroshi Matono ${ }^{1}$, Tatsuya Yoshida1 ${ }^{1}$, Kazuhiro Tanaka ${ }^{1}$, \\ Shuichi Matsuda ${ }^{1}$, Yoshinao Oda ${ }^{2}$ and Yukihide Iwamoto ${ }^{1}$
}

\author{
Address: ${ }^{1}$ Department of Orthopedic Surgery, Graduate School of Medical Sciences, Kyushu University, Fukuoka, 812-8582, Japan and \\ ${ }^{2}$ Department of Anatomic Pathology, Graduate School of Medical Sciences, Kyushu University, Fukuoka, 812-8582, Japan \\ Email: Akio Sakamoto* - akio@med.kyushu-u.ac.jp; Hiroshi Matono - h-matono@surgpath.med.kyushu-u.ac.jp \\ Tatsuya Yoshida -yoshidat@ortho.med.kyushu-u.ac.jp; Kazuhiro Tanaka - tanaka@ortho.med.kyushu-u.ac.jp; \\ Shuichi Matsuda - mazda@ortho.med.kyushu-u.ac.jp; Yoshinao Oda - oda@surgpath.med.kyushu-u.ac.jp; \\ Yukihide Iwamoto - yiwamoto@ortho.med.kyushu-u.ac.jp \\ * Corresponding author
}

Published: 16 November 2007

World Journal of Surgical Oncology 2007, 5:131 doi:10.1186/1477-7819-5-131

This article is available from: http://www.wjso.com/content/5/I//3।

(C) 2007 Sakamoto et al; licensee BioMed Central Ltd.

This is an Open Access article distributed under the terms of the Creative Commons Attribution License (http://creativecommons.org/licenses/by/2.0), which permits unrestricted use, distribution, and reproduction in any medium, provided the original work is properly cited.

\begin{abstract}
Background: Granulocyte-colony-stimulating factor (G-CSF) functions as a hematopoietic growth factor and it is responsible for leukocytosis. G-CSF-producing tumors associated with leukocytosis include various types of malignancies.

Case presentation: We report the case of a 72-year-old man with dedifferentiated liposarcoma characterized by dedifferentiated components of malignant fibrous histiocytoma (MFH)-like features in addition to well-differentiated lipoma-like liposarcoma, arising from his upper arm. Preoperative laboratory data showed leukocytosis $(103,700 / \mu \mathrm{l})$. The serum level of G-CSF was also elevated $(620 \mathrm{pg} / \mathrm{ml}$ [normal, $<8 \mathrm{pg} / \mathrm{ml}])$. Nine days after the surgery, the leukocytosis was relieved

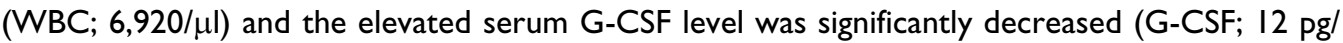
$\mathrm{ml})$. One month after the surgery, leukocytosis gradually began to appear again. Three months after the surgery metastatic lung lesions were confirmed, and the patient subsequently died of respiratory problems. In the English literature regarding soft-tissue tumors with leukocytosis, including the current case, we could review a total of 6 cases of liposarcoma with leukocytosis. The subtype of these 6 liposarcoma cases was undifferentiated liposarcoma, comprising dedifferentiated liposarcoma in 4 cases and pleomorphic liposarcoma in 2 cases.
\end{abstract}

Conclusion: Since the only other soft-tissue tumor that was associated with leukocytosis was $\mathrm{MFH}$, and since MFH is characterized by the absence of any specific differentiation, we would like to propose a possible association between G-CSF-producing soft-tissue tumors and an undifferentiated liposarcoma lineage, such as dedifferentiated liposarcoma or pleomorphic liposarcoma. 


\section{Background}

Granulocyte-colony-stimulating factor (G-CSF) enhances differentiation along the neutrophil lineage, and accelerates maturation of metamyelocytes into mature neutrophils. Consequently, G-CSF is known to function as a hematopoietic growth factor and it is known to be responsible for leukocytosis. G-CSF-producing tumors associated with leukocytosis include various types of malignancies. In epithelial cancers, the expression of GCSF has been associated with poor differentiation and invasiveness [1-3]. However, it is a rare event among softtissue tumors for leukocytosis to be associated with an elevated level of serum G-CSF. Furthermore, although malignant fibrous histiocytoma (MFH), which is characterized by the absence of any distinct differentiation, has been reported to be accompanied by leukocytosis [4-6], this is extremely rare in the case of soft-tissue tumors with specific differentiation.

\section{Case presentation}

A 72-year-old man who suffered from a tumor in his upper arm presented to us (Figure 1a, 1b). Body temperature was $38.1^{\circ} \mathrm{C}$. Histological diagnosis of the resected tumor was dedifferentiated liposarcoma characterized by a well-differentiated lipoma-like liposarcoma component (Figure 1c, 1d) and a dedifferentiated component with MFH-like features (Figure 1e).
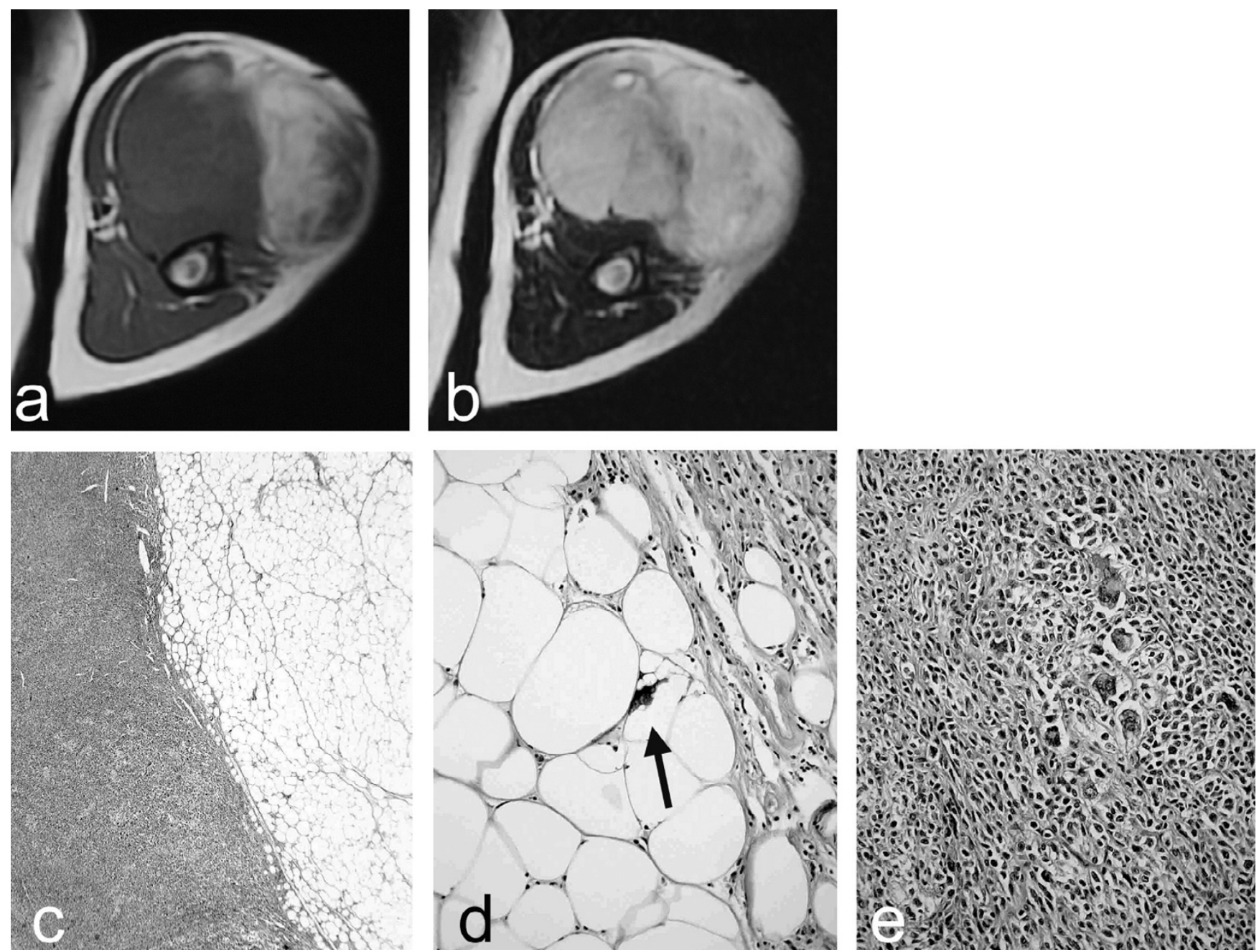

Figure I

MRI shows a tumor with two components of high TI-weighted (a) and high T2-weighted images (b) (right portion; well-differentiated components), and of low TI-weighted (a) and high T2-weighted images (b) (left portion; dedifferentiated components). Well-differentiated components and dedifferentiated components with a distinct border (c). Well-differentiated components show well-differentiated lipoma-like liposarcoma with lipoblasts (arrow) (d). Dedifferentiated components are composed of atypical spindle cells in short fascicles, resembling MFH (bottom; left) (e). 
Table I: Summary of blood data

\begin{tabular}{lllllllllll}
\hline Days from OPE & -4 & 2 & 9 & 17 & 24 & 31 & 37 & 44 & 52 & 60 \\
\hline WBC $\left(\times 10^{3}\right)$ & 103.7 & 33.8 & 6.92 & 4.2 & 4.0 & 11.5 & 13.4 & 23.1 & 43.5 & 100.0 \\
Neutrophils $(\%)$ & 91.5 & 88.0 & 80.6 & 69.1 & 61.5 & 87.5 & 83.2 & 90.6 & 93.7 & 96.6 \\
G-CSF $(\mathrm{pg} / \mathrm{ml})[\mathrm{normal},<8 \mathrm{pg} / \mathrm{ml}]$ & 620 & 44 & 12 & NA & NA & NA & NA & NA & NA & NA \\
\hline
\end{tabular}

OPE; operation, WBC; white blood cells, G-CSF; granulocyte-colony-stimulating factor, NA; not assessed

The blood data of white blood cells and serum level of GCSF are summarized in Figure 2 and Table 1. Preoperative laboratory data showed leukocytosis $(103,700 / \mu \mathrm{l})$ predominantly in the neutrophils (neutrophils; $91.5 \%$ [normal, 40-70\%]). The serum level of G-CSF was also elevated $(620 \mathrm{pg} / \mathrm{ml}$ [normal, $<8 \mathrm{pg} / \mathrm{ml}])$. Leukocytosis was relieved (white blood cells; 33,800/ $\mu$ l [neutrophils; $88.0 \%$ ] and $6,920 / \mu \mathrm{l}$ [neutrophils; $80.6 \%$ ]) and the elevated serum G-CSF level was significantly decreased (GCSF; $44 \mathrm{pg} / \mathrm{ml}$ and $12 \mathrm{pg} / \mathrm{ml}$ ), 2 and 9 days after the sur- gery, respectively. One month after the surgery leukocytosis gradually began to appear again. Three months after the surgery, metastatic lung lesions were confirmed, and the patient subsequently died of respiratory problems.

Expression of G-CSF (anti-G-CSF [Ab1], Calbiochem, San Diego CA, USA) failed to be detected not only in the welldifferentiated lipoma-like liposarcoma components, but also in the dedifferentiated components, immunohistochemically (data not shown).

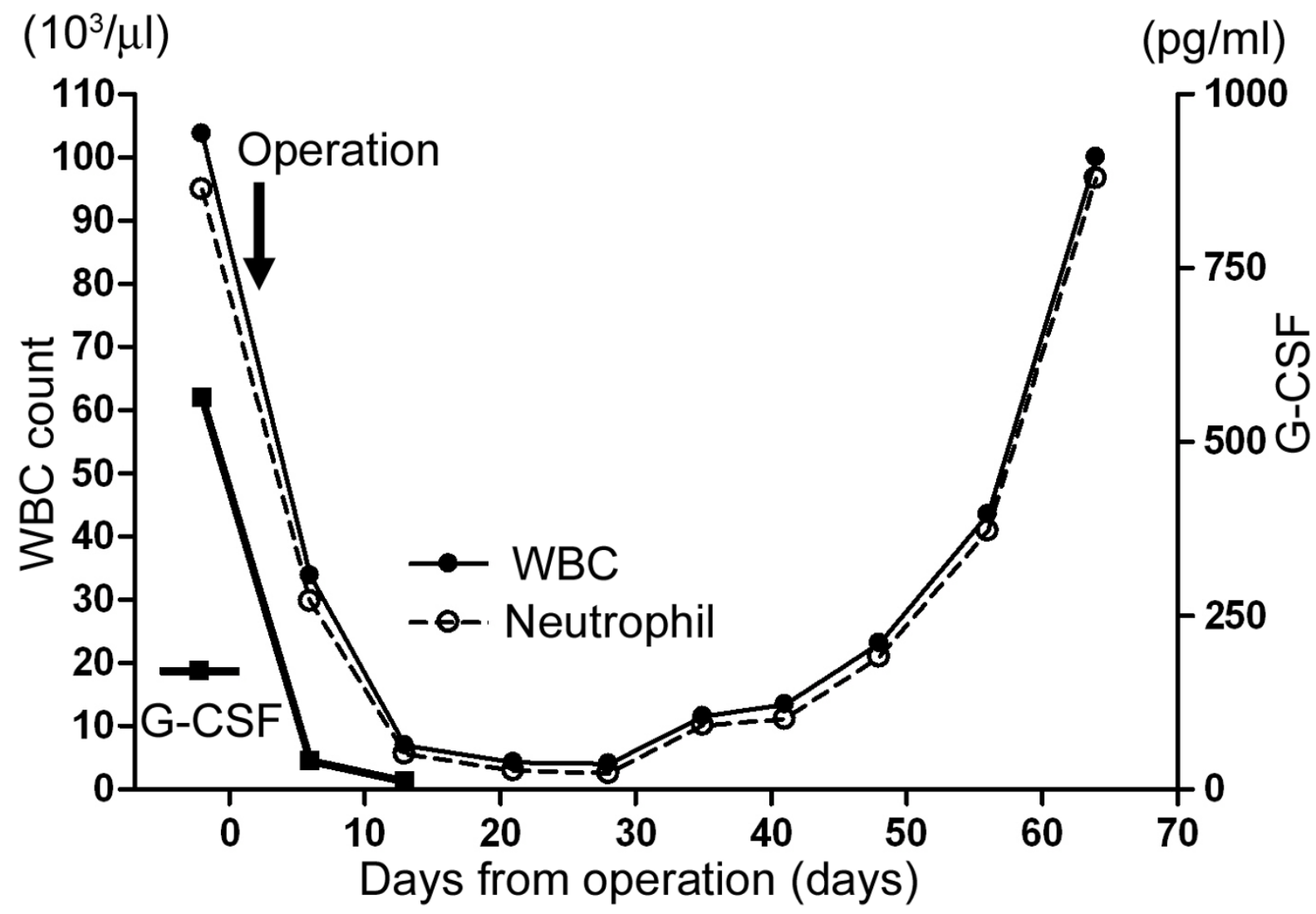

Figure 2

Time course of white blood cell count and serum G-CSF level. The count of white blood cells including neutophils, and the serum level of G-CSF decreased after surgery. 


\section{Discussion}

The leukocytosis seen in the current case with dedifferentiated liposarcoma seemed to be due to stimulation by the tumor-produced G-CSF, on the basis that both the leukocytosis and the elevated level of G-CSF disappeared after the tumor was resected. In a previous report, leukocytosis appeared at an advanced stage, as characterized by poorly differentiated adenocarcinoma, not in the early stage, as characterized by well-differentiated adenocaricnoma, in the same lesion of gastric cancer. In that gastric cancer case, immunopositivity of G-CSF was only seen in the poorly differentiated adenocarcinoma, not in the well-differentiated adenocarcinoma. It is thus possible that histological changes may influence the acquisition of G-CSFproducing ability [7]. In the current study, immunohistochemical study failed to detect any expression of G-CSF. It would seem that G-CSF-producing ability was acquired during the course of tumor progression, because leukocytosis appeared after noticeable tumor growth. It is also possible that the components of G-CSF-producing cells are heterogeneous in the tumor. Neoplastic cells in unexamined histological sections may express G-CSF, and an immunohistochemical study would have detected G-CSF expression.

In the English literature, including the current case, there have been 6 cases of liposarcoma accompanied by leukocytosis and associated with G-CSF expression [8-12]. Gender distribution was 3 males and 3 females, while the average age was 64.7 (range; 50-77) years. The sites were the following; retroperitoneum in 4 cases, mesenterium in 1 case and upper arm in 1 case. The subtype of these liposarcoma cases was dedifferentiated liposarcoma in 4 cases [10-12] and pleomorphic liposarcoma in 2 cases $[8,9]$. Pleomorphic liposarcoma showed the features of pleomorphic sarcoma, mimicking $\mathrm{MFH}$, and at least focally contained typical multivacuolated lipoblasts. In the case of epithelial tumors, G-CSF-producing tumors have been reported to be associated with poor differentiation [1-3]. Up until now, there have been no reported cases of well-differentiated liposarcoma with leukocytosis. Therefore, it may also be true that G-CSF expression is associated with undifferentiated liposarcoma, including both dedifferentiated liposarcoma and pleomorphic liposarcoma. Furthermore, it might be better to search for dedifferentiated components in an effort to provide a possible diagnosis of dedifferentiated liposarcoma, when well-differentiated liposarcoma is accompanied by leukocytosis.

MFH has been reported to be accompanied by leukocytosis, previously [4-6]. The diagnostic criteria of MFH are defined as "pleomorphic spindle cell sarcoma with no distinct line of differentiation". The diagnosis of MFH is commonly made by exclusion of other definitive sarco- mas, such as liposarcoma and leiomyosarcoma. Recently, after reassessment of pleomorphic sarcomas, the tumors in a certain number of cases have been proved to be specific sarcomas other than MFH. Therefore, there is the possibility that the reported case of MFH with leukocytosis actually had a liposarcoma lineage. In addition, among soft-tissue tumors with specific differentiation, there seem to be no reported cases with leukocytosis, besides liposarcoma. The association between G-CSF production and undifferentiated liposarcoma formation implies that they share the same signaling pathways in part.

In epithelial cancers, G-CSF expression has been associated with poor differentiation and invasiveness [1-3]. Moreover, G-CSF expression was reported to be linked to poor prognosis in patients with lung carcinoma [13]. GCSF has been shown to stimulate tumor cell growth and migration in vitro [14-17]. In a similar manner, G-CSF may have contributed to the aggressive behavior of dedifferentiated liposarcoma in the current case. A transcription factor STAT3 is a key mediator of G-CSF signaling. STAT3 potently promotes proliferation, survival, invasion and angiogenic effects through regulation of multiple gene products [18-21]. Survivin is one of the STAT3-regulated genes, and has an important function in regulating the growth of cancer cells [22]. It has been indicated that G-CSF potently activates STAT3 and STAT3-dependent survivin expression in bladder cancer cells [23]. Further examination would be necessary to confirm whether or not this mechanism holds true for liposarcoma.

\section{Conclusion}

In this report, we present a case of dedifferentiated liposarcoma with leukocytosis. The leukocytosis seemed to be associated with an elevated level of serum G-CSF. We would like to propose a possible association between GCSF-producing soft-tissue tumors and an undifferentiated liposarcoma lineage, such as dedifferentiated liposarcoma or pleomorphic liposarcoma.

\section{Competing interests}

The author(s) declare that they have no competing interests.

\section{Authors' contributions}

AS drafted the manuscript. HM performed the immunohistochemical study. TY, HM, KT, SM and YO participated in the design of the study. YI conceived of the study, and participated in its design and coordination and helped to draft the manuscript. All authors read and approved the final manuscript.

\section{Acknowledgements}

The patient's family was informed that data from the case would be submitted for publication, and the family members gave their consent. 
The English used in this manuscript was revised by Miss K. Miller (Royal English Language Centre, Fukuoka, Japan).

\section{References}

I. Savarese TM, Mitchell K, McQuain C, Campbell CL, Guardiani R, Wuu J, Ollari C, Reale F, Nelson BE, Chen A, Quesenberry PJ: Coexpression of granulocyte colony stimulating factor and its receptor in primary ovarian carcinomas. Cancer Lett 200I, I 62(I): I05-II5.

2. Chakraborty A, White SM, Guha S: Granulocyte colony-stimulating receptor promotes betal-integrin-mediated adhesion and invasion of bladder cancer cells. Urology 2006, 68(I):208-2I3.

3. Hirai K, Kumakiri M, Fujieda S, Sunaga H, Lao LM, Imamura Y, Ueda $K$, Fukuda M: Expression of granulocyte colony-stimulating factor and its receptor in epithelial skin tumors. J Dermatol Sci 200I, 25(3): I79-188.

4. Hamada T, Komiya S, Hiraoka K, Zenmyo M, Morimatsu M, Inoue A: IL-6 in a pleomorphic type of malignant fibrous histiocytoma presenting high fever. Hum Pathol 1998, 29(7):758-76I.

5. Melhem MF, Meisler AI, Saito R, Finley GG, Hockman HR, Koski RA: Cytokines in inflammatory malignant fibrous histiocytoma presenting with leukemoid reaction. Blood 1993, 82(7):2038-2044.

6. Mayumi E, Okuno T, Ogawa T, Kurata K, Ishioka H, Hamamoto $H$, Ishiki K, Maga T, Okamoto T, Yoshida T, Ogura Y: Malignant fibrous histiocytoma of soft tissue producing granulocyte colony-stimulating factor. Intern Med 200I, 40(6):536-540.

7. Yamano T, Morii E, Ikeda J, Aozasa K: Granulocyte colony-stimulating factor production and rapid progression of gastric cancer after histological change in the tumor. Jpn J Clin Oncol 2007, 37(I 0):793-796.

8. Matsumoto M, Yazawa Y, Kanzaki M: An autopsy case of liposarcoma with granulocytic leukemoid reaction. Acta Pathol Jpn 1976, 26(3):399-408.

9. Nakamura A, Tanaka S, Takayama H, Sakamoto M, Ishii H, Kusano M, Onizuka Y, Ota S, Mitamura K: A mesenteric liposarcoma with production of granulocyte colony-stimulating factor. Intern Med 1998, 37(10):884-890.

10. Hisaoka M, Tsuji S, Hashimoto H, Aoki T, Uriu K: Dedifferentiated liposarcoma with an inflammatory malignant fibrous histiocytoma-like component presenting a leukemoid reaction. Pathol Int 1997, 47(9):642-646.

II. Nasser SM, Choudry UH, Nielsen GP, Ott MJ: A leukemoid reaction in a patient with a dedifferentiated liposarcoma. Surgery 200I, I 29(6):765-767.

12. des Guetz G, Mariani P, Freneaux P, Pouillart P: Paraneoplastic syndromes in cancer: Case 2 . Leucocytosis associated with liposarcoma recurrence: original presentation of liposarcoma recurrence. J Clin Oncol 2004, 22(I I):2242-2243.

13. Kasuga I, Makino S, Kiyokawa H, Katoh H, Ebihara Y, Ohyashiki K: Tumor-related leukocytosis is linked with poor prognosis in patients with lung carcinoma. Cancer 200I, 92(9):2399-2405.

14. Mueller MM, Herold-Mende CC, Riede D, Lange M, Steiner HH, Fusenig NE: Autocrine growth regulation by granulocyte colony-stimulating factor and granulocyte macrophage colonystimulating factor in human gliomas with tumor progression. Am J Pathol 1999, I 55(5): I557-I567.

15. Mueller MM, Fusenig NE: Constitutive expression of G-CSF and GM-CSF in human skin carcinoma cells with functional consequence for tumor progression. Int J Cancer 1999, 83(6):780-789.

16. Obermueller E, Vosseler S, Fusenig NE, Mueller MM: Cooperative autocrine and paracrine functions of granulocyte colonystimulating factor and granulocyte-macrophage colonystimulating factor in the progression of skin carcinoma cells. Cancer Res 2004, 64(2I):780I-78I2.

17. Pei XH, Nakanishi Y, Takayama K, Bai F, Hara N: Granulocyte, granulocyte-macrophage, and macrophage colony-stimulating factors can stimulate the invasive capacity of human lung cancer cells. Br J Cancer 1999, 79(I):40-46.

18. Gritsko T, Williams A, Turkson J, Kaneko S, Bowman T, Huang M, Nam S, Eweis I, Diaz N, Sullivan D, Yoder S, Enkemann S, Eschrich S, Lee JH, Beam CA, Cheng J, Minton S, Muro-Cacho CA, Jove R: Persistent activation of stat 3 signaling induces survivin gene expression and confers resistance to apoptosis in human breast cancer cells. Clin Cancer Res 2006, I 2(I): I I- I9.

19. Coppo P, Flamant S, De Mas V, Jarrier P, Guillier M, Bonnet ML, Lacout C, Guilhot F, Vainchenker W, Turhan AG: BCR-ABL activates STAT3 via JAK and MEK pathways in human cells. $B r$ J Haematol 2006, I34(2): I7|-I79.

20. Yin W, Cheepala S, Roberts JN, Syson-Chan K, DiGiovanni J, Clifford $J \mathrm{~L}$ : Active Stat3 is required for survival of human squamous cell carcinoma cells in serum-free conditions. Mol Cancer 2006 , 50:15-23.

21. Kotha A, Sekharam M, Cilenti L, Siddiquee K, Khaled A, Zervos AS, Carter B, Turkson J, Jove R: Resveratrol inhibits Src and Stat3 signaling and induces the apoptosis of malignant cells containing activated Stat3 protein. Mol Cancer Ther 2006 , 5(3):62|-629.

22. Fesik SW: Promoting apoptosis as a strategy for cancer drug discovery. Nat Rev Cancer 2005 , 5( I I):876-885.

23. Chakraborty A, Guha S: Granulocyte colony-stimulating factor/ granulocyte colony-stimulating factor receptor biological axis promotes survival and growth of bladder cancer cells. Urology 2007, 69(6): $1210-1215$.
Publish with Biomed Central and every scientist can read your work free of charge

"BioMed Central will be the most significant development for disseminating the results of biomedical research in our lifetime. "

Sir Paul Nurse, Cancer Research UK

Your research papers will be:

- available free of charge to the entire biomedical community

- peer reviewed and published immediately upon acceptance

- cited in PubMed and archived on PubMed Central

- yours - you keep the copyright

Submit your manuscript here:

http://www.biomedcentral.com/info/publishing_adv.asp
BioMedcentral 